\title{
Use of a patient classification instrument as a guide to plan nursing discharge*
}

\author{
Uso de instrumento de classificação de pacientes como norteador do planejamento de alta de \\ enfermagem \\ Uso de un instrumento de clasificación de pacientes como guía de la planificación del alta de \\ enfermería
}

Fernanda Collinetti Pagliarini ${ }^{1}$, Marcia Galan Perroca ${ }^{2}$

\begin{abstract}
Objective: To evaluate the use of a patient classification instrument as a guide to plan nursing discharge. Methods: Exploratory descriptive study performed in hospitalization units of Medical and Surgical Practice at a teaching hospital in São José do Rio Preto - SP, Brazil. The sample was made up of 50 patients who received discharge guidance from seven clinical nurses and supervisors. The sample collection occurred in two steps after the record of the discharge guidance, performed by nurses with and without the aid of a classification instrument. Results: The findings show that nurses are more likely to comply with care areas in the psychobiological dimension. However, when they use the instrument, the psychosocial dimension is also benefited. Conclusion: The use of a patient classification instrument guided the planning of nursing discharge, enabling a more comprehensive and more thorough identification of care areas that require attention.

Keywords: Inpatients/classification; Workload; Nursing assessment; Patient discharge
\end{abstract}

\section{RESUMO}

Objetivo: Avaliar a utilização de um instrumento de classificação de pacientes como norteador do planejamento de alta de enfermagem. Métodos: Estudo descritivo exploratório realizado em unidades de internação de Clínica Médica e Cirúrgica de um hospital de ensino na cidade de São José do Rio Preto -SP. A amostra consistiu em 50 pacientes que receberam orientações de alta de sete enfermeiras clínicas e supervisoras. A coleta de dados ocorreu em duas etapas mediante o registro das orientações de alta realizadas pelas enfermeiras sem e com o auxílio de instrumento de classificação. Resultados: Revelam que as enfermeiras se atêm mais às áreas de cuidados da dimensão psicobiológica. Contudo, quando utilizam o instrumento, a dimensão psicosocial passa também a ser privilegiada. Conclusão: A utilização de instrumento para classificação de pacientes norteou o planejamento de alta de enfermagem, possibilitando uma identificação mais abrangente e mais aprofundada das áreas de cuidado que requerem atenção.

Descritores: Pacientes internados/classificação; Carga de trabalho; Avaliação em enfermagem; Alta do paciente

\section{RESUMEN}

Objetivo: Evaluar la utilización de un instrumento de clasificación de pacientes como guía de la planificación del alta de enfermería. Métodos: Se trata de un estudio descriptivo exploratorio realizado en unidades de internamiento de una Clínica Médica y Quirúrgica de un hospital de enseñanza en la ciudad de Sao José do Rio Preto -SP. La muestra estuvo conformada por 50 pacientes que recibieron orientaciones de alta de siete enfermeras clínicas y supervisoras. La recolección de datos se llevó a cabo en dos etapas mediante el registro de las orientaciones de alta realizadas por las enfermeras sin y con la ayuda de un instrumento de clasificación. Resultados: Revelan que las enfermeras se atienen más a las áreas de cuidados de la dimensión psicobiológica. Con todo, cuando utilizan el instrumento, la dimensión psicosocial pasa también a ser privilegiada. Conclusión: La utilización de un instrumento para la clasificación de pacientes guió la planificación del alta de enfermería, haciendo posible una identificación más incluyente y más profunda de las áreas de cuidado que requieren atención. Descriptores: Pacientes internos/clasificación; Carga de trabajo; Evaluación en enfermería; Alta del paciente

\footnotetext{
${ }^{*}$ Extracted from the final paper presented to the undergraduate nursing course at the Faculdade de Medicina de São José do Rio Preto - FAMERP - São José do Rio Preto, (SP), Brazil.

${ }^{1}$ Nurse graduated in the undergraduate Nursing course atthe Faculdade de Medicina de São José do Rio Preto (FAMERP) - São José do Rio Preto, (SP), Brazil. Currently specializing in Oncology at EERP/USP.

${ }^{2}$ Ph.D. in Nursing. Professor of the Specialized Nursing Department of the Faculdade de Medicina de São José do Rio Preto (FAMERP) - São José do Rio Preto, (SP), Brazil.
} 


\section{INTRODUCTION}

Hospital discharge encompasses the continuity of treatment at home, regardless of whether it is performed by the patient, family members and/or caregivers ${ }^{(1)}$. In the past decades, the need to mitigate costs has reduced the stay in hospital institutions, affecting patients and health team members. The patients began to receive discharge with a higher level of care complexity, demanding more attention. The health team began to have less time to educate the patients and their family members regarding home care and to coordinate services and, thus, the discharge plans became inappropriate. Consequently, there was an increased readmission rate, with an care cost increase and effects on patients' health ${ }^{(2)}$.

Since then, the contribution of effective hospitalhome transition planning to patients' health has been acknowledged, and discharge planning has become an integral part of health care ${ }^{(3)}$. Effective discharge planning can be defined as the construction and implementation of a planned program for care continuity, which satisfies the needs of the patient after hospital discharge ${ }^{(4)}$, equally incorporating psychological, economic and social aspects $^{(3)}$. The discharge planning is advised to start after admission to the hospital institution, and embodies four steps: evaluation of the patients' needs; development of discharge planning; patient/family education, mobilizing the necessary resources and services; and accompaniment and evaluation, usually the responsibility of community services ${ }^{(2)}$.

Even though the discharge process is considered to be multidisciplinary, the nurse plays a fundamental role, either acting to identify the patients' needs, patient and family education or coordinating the process ${ }^{(3,5)}$. Education is an essential component when it comes to care delivery and the nurses have more opportunities to educate the patients in comparison with other professionals. However, this activity has often been neglected because there is, in professional practice, a lower degree of involvement of clinical nurses in patient education ${ }^{(6)}$. Reports of nurses regarding more developed activities in hospitalization units show that educational actions with patients represent only $7.1 \%$ when compared to other activities ${ }^{(7)}$. However, a closer look at the activities decreases this percentage to $4.1 \%{ }^{(8)}$.

The Patient Classification System (PCS) was conceived in the sixties, in the United States, to identify the patients' individualized care needs, grouping them in care categories ${ }^{(9-10)}$. Originally used to determine the nursing team workload and, thus, support staff allocation and dimensioning, the purposed of the PCS gradually expanded during the following decades, marked by the proliferation of different systems, mainly in the United
States and Canada ${ }^{(11)}$.

The literature has pointed out several benefits of using patient classification, such as the improvement of care quality provided by the individualization of the patients' needs and the construction of a database, containing information regarding decision making; care planning, monitoring of productivity and nursing service costs ${ }^{(0-10)}$.

There are several studies about patient classification. However, the focus is on development ${ }^{(12-13)}$ and instrument validation $^{(14)}$ and/or characterization of the client profile at a given hospitalization unit, including nursing staff dimensioning ${ }^{(15-16)}$. Even though the patient classification instrument is considered an important tool for nursing care planning, few studies have explored this segment. Reduced time, nurse involvement in multiple activities and little importance attributed to educational activities have turned discharge planning into a superficial and routine activity, without a deeper evaluation of the patients' care needs, to mobilize resources and services in the community. In view of this problem, there was speculation on whether the use of a classification instrument, whose structure benefits care areas related to psychobiological and psychosocial dimensions, would aid nurses to fully picture the patients' care needs, contributing to elaborate effective nursing discharge planning.

\section{OBJECTIVE}

To evaluate the use of a patient classification instrument as a guide to plan nursing discharge.

\section{METHODS}

This descriptive, exploratory study was performed at two hospitalization units of Medical Practice and two Surgical Practices of a teaching hospital in the countryside of São Paulo State. It proposes to compare an intervention (discharge guidance by the nurse) before and after the application of a patient classification instrument by care complexity ${ }^{(12)}$. The sample consisted of 50 patients who received discharge guidance from seven clinical nurses and supervisors working at these hospitalization units. The sample was collected after the project had been approved by the Committee of Ethics and after participants had signed the full consent form, in August and September, in two steps. In the first step, the nurses recorded the discharge guidance of 25 patients performed without the aid of a patient classification instrument and, at the same time, one of the researchers evaluated these patients by using the instrument ${ }^{(12)}$; in the second step, the nursing discharge guidance of 25 other patients were based on the classification instrument. This instrument ${ }^{(12)}$ is based on individualized nursing care needs and focused on adult patients. It is composed of 13 care areas: Mental Status 
and Conscience Level, Oxygenation, Vital Signs, Nutrition and Hydration, Motility, Locomotion, Bodily Care, Eliminations, Therapeutics, Education for Health, Behavior, Communication and Cutaneous and Mucosal Integrity. Each of the indicators varies on a scale of 1 (lowest level of nursing care) to 5 (maximum level of care complexity). The minimum score is 13 and the maximum 65 points. Through this instrument, the patient can be classified in one of the four care categories: Minimum (13-26 points), Intermediate (27-39 points), Semi-Intensive (40-52 points) and Intensive (53-65 points).

At the institution, due to the absence of a standardized form to guide discharge, the nurses were asked to record their notes on a form elaborated by the researchers. This form was composed of two parts: the first included the patients' identification data and the second spaces reserved for discharge notes. The nurses were previously aware of the classification instrument and its operationalization, not needing any guidance.

The interpretation structure of the discharge guidance contents in both steps was as following: careful reading of the material; keywords of the prescribed guidance in bold; identification of the care areas they belonged to according to the classification instrument (E.g.: Bodily care); frequency list of the care areas found by the patients and the respective guidance. The findings were treated as frequencies, mean and standard deviation, and calculated through Microsoft Office Excel.

\section{RESULTS}

The results will be presented in two parts, according to the steps of the study. The first shows the data obtained with the aid of the patient classification (PCS), and the second its use by the nurses. The patients' demographic data in both steps of the research showed to be similar (Table 1).

\section{Discharge Guidance - Step 1}

Analyzing the content of the nurses' discharge guidance with the first 25 patients, without the aid of the classification instrument, 82 care areas were identified, a mean of 3.28 $( \pm 1.2)$ per patient. The care areas that received more nursing attention were Therapeutics ( $\mathrm{n}=19)$, Cutaneous and Mucosal Integrity $(n=17)$, Nutrition/Hydration $(n=12)$ and Locomotion $(\mathrm{n}=8)$. Communication was the area that received less attention $(n=1)$. Among the most common guidance concerning care areas, the following stood out: how to administer the prescribed medication, the dosage and time (Therapeutics); wound dressing, frequency, products, preventive measures against pressure ulcers in elderly or bedridden patients (Cutaneous and Mucosal Integrity); care with the nasoenteral probe, administration of diet and medication, care with water intake, guidance regarding diet (Nutrition/Hydration); and guidance related to patients whose locomotion relied on artifacts (Locomotion).

Table 1 - Distribution of patients according to demographic data, time of permanence in hospital and medical expertise

\begin{tabular}{|c|c|c|}
\hline Variables & $1^{\text {st }}$ Phase $(n=25)$ & $2^{\text {nd }}$ Phase $(n=25)$ \\
\hline \multicolumn{3}{|l|}{ Age } \\
\hline Mean (SD) & $49.9(21.7)$ & $51.2(21.4)$ \\
\hline Variation & 15-89 & 19-89 \\
\hline \multicolumn{3}{|l|}{ Gender } \\
\hline Female & 7 & 10 \\
\hline Male & 18 & 15 \\
\hline \multicolumn{3}{|c|}{$\begin{array}{l}\text { Time of } \\
\text { Permanence (days) }\end{array}$} \\
\hline Mean (SD) & $10.6(12.7)$ & $10.4(10.4)$ \\
\hline Variation & $2-52$ & $3-48$ \\
\hline Not identified & 5 & - \\
\hline \multicolumn{3}{|c|}{ Medical Expertise } \\
\hline Gastrology & 6 & 2 \\
\hline Neurology & 6 & 6 \\
\hline Orthopedics & 5 & 5 \\
\hline Pneumology & 3 & 6 \\
\hline Geriatrics & 2 & - \\
\hline Oncology & 1 & 5 \\
\hline Dermatology & 1 & - \\
\hline Proctology & 1 & 1 \\
\hline
\end{tabular}

When these 25 patients were evaluated by a researcher with the use of a patient classification instrument, 149 care areas were identified and required nursing intervention, a mean of $5.96( \pm 3.0)$ per patient. The care areas most identified by the instrument were: Therapeutics $(n=20)$, Cutaneous and Mucosal Integrity $(n=17)$, Nutrition/Hydration ( $n=16)$, Bodily Care $(n=16)$, Vital Signs $(n=15)$ and Eliminations $(n=14)$. The guidance related to the Therapeutics and Cutaneous and Mucosal Integrity were the most recorded, in the discharge form as well as in the classifications (Table 2).

\section{Discharge Guidance - Step 2}

In the second phase of the research, when the nurses performed the discharge guidance of other 25 patients by using the patient classification instrument, 115 care areas were detected, a mean of $4.6( \pm 2.6)$. The care areas that received greater nursing attention were Therapeutics $(\mathrm{n}=18)$, Education for Health $(\mathrm{n}=15)$, Nutrition/ Hydration $(n=13)$ Eliminations and Locomotion, both with $(n=10)$. In this phase, the guidance provided to the patient/family was more detailed and other aspects were also discussed, such as the allocation of resources in the community, support group for a certain diagnosis, selfcare and family participation in rehabilitation, participation of caregiver to help patients with difficulties in communication and language disorders and/or emotional problems; to be referred to other professionals 
(Communications/Behavior); to control vital parameters and glucose of elderly and hypertensive patients. In the Elimination care area, the guidance was majorly on care with stomas and monitoring of the eliminations due to constipation/diarrhea. Other approaches were equally used by nurses, such as: family behavior towards patient with Alzheimer or patients with mental disorders, search for support groups (Table 3).

Table 2 - Distribution of care areas observed through the use of patient classification instrument and the content of nurses' discharge guidance (without instrument)

\begin{tabular}{lcc}
\hline Care Area & $\begin{array}{c}\text { Without Instrument } \\
(\mathbf{n}=\mathbf{2 5})\end{array}$ & $\begin{array}{c}\text { With Instrument } \\
(\mathbf{n}=\mathbf{2 5})\end{array}$ \\
\hline Mental Status and & 2 & 6 \\
Conscience Level & 3 & 3 \\
Oxygenation & 3 & 15 \\
Vital Signs & 12 & 16 \\
Nutrition and & 3 & 13 \\
Hydration & 8 & 12 \\
Motility & 5 & 16 \\
Locomotion & 6 & 14 \\
Bodily Care & 19 & 20 \\
Eliminations & 3 & 4 \\
Therapeutics & - & 8 \\
Education for Health & 1 & 5 \\
Behavior & 17 & 17 \\
Communication & $\mathbf{8 2}$ & $\mathbf{1 4 9}$ \\
Cutaneous and & & \\
Mucosal Integrity & & \\
\hline Total & &
\end{tabular}

Table 3-Distribution of care areas observed by the use of patient classification instrument guiding nurses' discharge

\begin{tabular}{lc}
\hline Care Area & $\begin{array}{c}\text { With Instrument } \\
(\mathbf{n}=\mathbf{2 5})\end{array}$ \\
\hline Mental Status and Conscience Level & 4 \\
Oxygenation & 5 \\
Vital Signs & 4 \\
Nutrition and Hydration & 13 \\
Motility & 8 \\
Locomotion & 10 \\
Bodily Care & 7 \\
Eliminations & 10 \\
Therapeutics & 18 \\
Education for Health & 15 \\
Behavior & 3 \\
Communication & 3 \\
Cutaneous and Mucosal Integrity & 15 \\
\hline Total & $\mathbf{1 1 5}$ \\
\hline
\end{tabular}

\section{DISCUSSION}

Several authors recognize that discharge planning still remains problematic and many questions have been raised about its effectiveness ${ }^{(2-3,17)}$. The inappropriate preparation of patients and relatives and the consequent lack of knowledge and information concerning several aspects of home care $^{(6)}$ contribute to the return of patients to the hospital with problems that could have been avoided, or even controlled ${ }^{(2)}$. Although the nurses acknowledge being responsible for the coordination of the discharge planning process and also that the identification of the care needs should be done during the hospitalization period $^{(3)}$, in practice, the guidance provided to patients and relatives to guarantee care continuity is still reduced ${ }^{(18)}$.

The findings in this study have evidenced an expressive increase of $71.3 \%$ in the identification of the care needs at the moment of hospital discharge by using the patient classification instrument. These instruments are composed of care areas that discuss the psychobiological, psychosocial and psychospiritual dimensions ${ }^{(0-10)}$. Thus, they allow for patient evaluation in a holistic perspective, broadening the scope of guidance provided and preventing the nurses from relying solely on routine guidance. Another study at the same hospital, looking at the nurse's role in hospital discharge, showed that guidance was performed according to each professional's viewpoint and was limited to medicine administration at home and return for medical control ${ }^{(19)}$.

In the first phase of the research, when discharge guidance to the patient/family was performed without the aid of instruments, the guidance was based on the needs in the psychobiological dimensions, rather than in the psychosocial dimension. There was little concern with care areas like behavior and communication. The findings show that nurses advised the patient/ family regarding the most basic and evident needs such as Therapeutics, Cutaneous and Mucosal Integrity, Nutrition and Hydration. Despite the fact that guidance regarding medicine therapeutics was the most identified area in the present study, other findings reveal that this guidance has been performed inappropriately, too short and without certifying patients' understanding ${ }^{(18)}$.

In the second phase of the study, when the instrument was used, the scope was higher, the distribution of care areas was more equal, and more comprehensive and detailed guidance was provided. The use of a classification instrument guided the nurses to elicit resource mobilization and community services to patients, the search for support groups, reintegration in social life and referral to other services. Family participation in rehabilitation has gained more attention. The nurse is expected to work in partnerships, involving family, because she is the one who will resume treatment at home. Thus, the family should be involved in all planning steps so as to understand the patients' health status and needs. The valuation of the social aspects of patient care is considered of fundamental importance, as it is an integral part of the discharge process $^{(17)}$.

Through the findings in this study, it is important to consider the hospital discharge process, as well as the 
contribution the use of classification instruments represent when planning patients' care needs at home. It is fundamental to perceive nursing discharge planning as inherent to the care process, and also nurses' awareness to act more intensely in educational activities, because they constitute an essential component for post-discharge selfcare ${ }^{(2-3)}$.

With these statements, nurses who act in management activities are advised to search and establish strategies to minimize or even eliminate the factors that restrict the practice of the clinical nurse when planning discharge, redesigning the work process and promoting suitable quantitative and qualitative nursing staff dimensioning. The use of classification instruments to guide nursing discharge planning

\section{REFERENCES}

1. Pearlman IR. Discharge planning: the team is behind you! Nurs Manage. 1984; 15(8):36-8.

2. Mamon J, Heinwachs DM, Fahey M, Bone LR, Oktay J, Klein L. Impact of hospital discharge planning on meeting patient needs after returning home. Health Serv Res. 1992; 27(2):155-75.

3. Watts R, Gardner H. Nurses' perceptions of discharge planning. Nurs Health Sci. 2005; 7(3):175-83.

4. Houghton A, Bowling A, Clarke KD, Hopkins AP, Jones I. Does a dedicated discharge coordinator improve the quality of hospital discharge? Qual Health Care. 1996; 5(2): 89-96.

5. 5.Jackson MF. Discharge planning: issues and challenges for gerontological nursing. A critique of the literature. J Adv Nurs. 1994; 19(3):492-502.

6. Holloway A. Patient knowledge and information concerning medication on discharge from hospital. J Adv Nurs. 1996; 24(6):1169-74.

7. Costa RA, Shimizu HE. Estudo das atividades desenvolvidas pelos enfermeiros em um hospital-escola. Rev Esc Enferm USP. 2006; 40(3):418-26.

8. Costa RA, Shimizu HE. Atividades desenvolvidas pelos enfermeiros nas unidades de internação de um hospitalescola. Rev Latinoam Enferm. 2005; 13(5):654-62.

9. Giovannetti P. Understanding patient classification systems. J Nurs Adm. 1979; 9(2): 4-9.

10. De Groot HA. Patient classification system evaluation. Part 1: Essential system elements. J Nurs Adm. 1989; 19(6): 30-5.

11. Malloch K, Conovaloff A. Patient classifications systems, Part can constitute another strategy to optimize integral care delivery to the patient and promote preparation for quality discharge, since many care areas the nurses did not discuss in their discharge planning were identified by the instrument.

\section{CONCLUSION}

This study allowed to conclude that the use of a patient classification instrument guided the planning of nursing discharge, enabling a more comprehensive and more thorough identification of care areas that require attention. However, as this study is exploratory, it shows certain limitations and should be replicated in other contexts. Effective nursing discharge planning still poses challenges.

1: The third generation. J Nurs Adm. 1999; 29(7-8):49-56.

12. Perroca MG, Gaidzinski RR. Sistema de classificação de pacientes: construção e validade de um instrumento. Rev Esc Enferm USP. 1998; 32(2):153-68.

13. Fugulin MFT, Silva SH, Shimizu HE, Campos FPF. Implantação do sistema de classificação de pacientes na unidade de Clínica Médica do Hospital Universitário de São Paulo. Rev Med HU-USP. 1994; 4(1/2):63-8.

14. 14 Perroca MG. Instrumento de classificação de pacientes de Perroca: validação clínica. [tese]. São Paulo: Escola de Enfermagem da Universidade de São Paulo; 2000.

15. 15 Laus AM. Dimensionamento de pessoal de enfermagem para unidades de internação médicas e cirúrgicas no Hospital das Clinicas da Faculdade de Medicina de Ribeirão Preto USP [tese ]. Ribeirão Preto: Escola de Enfermagem de Ribeirão Preto da Universidade de São Paulo; 2003.

16. Nicola AL, Anselmi ML. Dimensionamento de pessoal de enfermagem em um hospital universitário. Rev Bras Enferm. 2005; 58(2):186-90.

17. Atwal A. Nurses' perceptions of discharge planning in acute health care: a case study in one British teaching hospital. J Adv Nurs. 2002; 39(5):450-8.

18. Miasso AI, Cassiani SHB. Administração de medicamentos: orientação final de enfermagem para a alta hospitalar. Rev Esc Enferm USP. 2005; 39(2):136-44.

19. Pompeo DA, Pinto MH, Cesarino CB, Araújo RRDF, Poletti NAA. Nurses' performance on hospital discharge: patients' point of view. Acta Paul Enferm. 2007; 20(3):345-50. 